\title{
Potential use of the nisin produced by lactic acid bacteria for longer conservation of Camel cheese
}

\author{
Wafa Souid ${ }^{1}$, Saliha Boudjenah-Haroun ${ }^{1 *}$, Oum El Kheir Siboukeur ${ }^{1}$, Abderrahmane Mati² \\ ${ }^{1}$ University of Ouargla, Faculty of Sciences de la Nature et de la vie, Lab. de Recherche sur la Phœniciculture, Ouargla 30000, Algeria: \\ ${ }^{2}$ Laboratoire de recherche de Biochimie Analytique et Biotechnologies (LABAB), Université Mouloud Mammeri de Tizi Ouzou, 15 000, Algérie
}

\section{A B S T R A C T}

\begin{abstract}
In fermented foods, lactic acid bacteria (LAB) display numerous antimicrobial activities. This is mainly due to the production of organic acids, but also of other compounds, such as bacteriocins and antifungal peptides. Several bacteriocins with industrial potential have been purified and characterized. This study aims to highlight on the antagonistic effect of lactic strain producer of bacteriocin (Lactococcus lactis ssp. Lactis) against a psychrotrophic strain (Pseudomonas fluorescens) contaminating the milk stored in the cold. The strain producing lactic bacteriocins (nisin-type) is isolated from a fresh camel cheese prepared in the laboratory with a significant yield, equal to $35.5 \%$. The indicator strain is a psychrotrophic strain isolated from a sample of raw camel milk, stored at $4^{\circ} \mathrm{C}$ for more than three days. Thus, the neutralized supernatant of a culture of Lactococcus lactis ssp. Lactis in M17 medium ( $8000 \mathrm{~g} / 20 \mathrm{~min}$ at $\left.4^{\circ} \mathrm{C}\right)$ was tested against the strain of Pseudomonas fluorescens by the three techniques of gel diffusion; spots, wells and disks. The neutralized supernatant showed antibacterial activity which was manifested by the appearance of inhibition zones where diameter differs depending on the test used. Diameters varying between 9 and $18 \mathrm{~mm}$ and between 12 and $29 \mathrm{~mm}$ were recorded respectively with wells and disks. The technique of spots has been less conclusive.
\end{abstract}

Keywords: Dromedary; Lactococcus lactis ssp.lactis; Milk; Nisin; Pseudomonas fluorescens

\section{INTRODUCTION}

Camel milk, like other mammals, is a medium with a complex chemical and physical composition allowing the camel to meet its energy and nutrient requirements during the first stage of its existence (Kamoun and Ramet, 1989).

Processing camel milk is considered difficult, including cheese making (Faye et al., 1997; Konuspayeva et al., 2014). The ability of a milk cheese processing is closely linked to the nature of its constituents (Goursaud, 1985), Kamoun and Ramet (1989), Akhmetsadykova et al. (2013) and Konuspayeva et al. (2014) have shown the ability to transform this milk into cheese with a satisfactory shelf, if we take into account the peculiarities inherent to its physicochemical composition. More recently, work undertaken at the University of Ouargla showed that the substitution of enzymes commonly used in cheese (commercial rennet) by gastric proteases from the stomachs of adult camels improves the ability of camel milk to coagulate (Boudjenahharoun et al., 2011).
On the other hand, during the milk cooling, psychrotrophic bacteria are able to produce thermostable lipolytic and proteolytic enzymes, causing bad taste in cheese (bitter taste, and unwanted off-flavors.) (Le jaouen, 1993). These micro-organisms present in raw milk, have the ability to grow at low temperature $\left(4-8^{\circ} \mathrm{C}\right)$. Among the incriminated flora is the genus Psendomonas, especially the species Pseudomonas fluorescens (Law and Haandrikman, 1997).

At temperatures below $10^{\circ} \mathrm{C}$, lactic milk flora is no longer dominant, and other micro-organisms considered harmful in cheese such as psychrotrophic become dominant (Le Jaouen, 1993). The lactic acid bacteria can produce numerous antimicrobial metabolites such as organic acids, hydrogen, carbon dioxide, reuterin, diacetyl peroxide and bacteriocins. These last are antimicrobial peptides which inhibit the growth of spoilage bacteria or pathogens (Dortu and Thonart, 2009). In food industry, only Lactococcus lactis's nisin is permitted as a food additive (E 234) since 1969 by WHO (World Health Organization). According to the Generally Recognized As Safe (GRAS), nisin inherit

\footnotetext{
*Corresponding author:

Saliha Boudjenah Haroun, Université kasdi merbah, faculté des sciences de la nature et de la Vie, laboratoire de echerché sur la phoeniciculture,Ouargla 30000 Algeria. Phone: 213 29716111. E-mail: salihaboudjenahharoun@yahoo.fr
} 
a broad spectrum of antibacterial activity directed mainly against Gram positive bacteria. Nisin is effective against pathogens such as Listeria monocytogenes, Stapbylococcus aureus, and Clostridium tyrobuturicum (Kalchayanand et al., 2008.).

This study aims to highlight on the antagonistic effect of a lactic bacteriocin producer strain (Lactococcus lactis ssp. Lactis) against psychrotrophic strain (Pseudomonas fuorescens) which contaminate milk.

\section{MATERIALS AND METHODS}

\section{Camel milk}

The camel milk was collected early morning from a free range camel herd (Camelus dromedarius), Sahraoui breed, in good health, living in the South-East Ouargla region (Algeria)

\section{Preliminary analyzes}

The sample of milk was transported in sterile bottles in a cooler to the laboratory for experiencing analysis, physicochemical ( $\mathrm{pH}$, acidity and density) and microbiological (reductase assay).

\section{Cheese making}

Cheese was made with gastric extract enzymes obtained from abomasums of older camel adopting the method described by Valles and Furet (1977). This extract possesses high clotting activity $(0.360 \mathrm{RU})$ and low proteolytic activity (Boudjenah-haroun et al., 2011). Ramet's diagram, 1993 for the production of camel cheese was followed. Curd stay was obtained and the cheese yield was calculated.

\section{Isolation of nisin-producing strain}

Isolation of nisin produced from cheese strain was achieved according Edima (2007). The method involves taking a sample of cheese $(10 \mathrm{~g})$ and mixed with $90 \mathrm{ml}$ of citrate buffer at $2 \%$. After crushing with Stomacher for 3 minutes at ambient temperature, the resulting suspension is subjected to successive decimal dilutions in the same buffer until reaching a dilution required for bacterial isolation $\left(10^{-8}\right)$.

\section{Identification of the nisin producing strain}

Identification of the isolated strain was done through exams: macroscopic (aspects of colonies), microscopic (after staining GRAM), tests (catalase and oxidase) and tests from the gallery of SHERMAN: culture in nutrient broth $\left(45^{\circ} \mathrm{C}, \mathrm{pH}\right.$ 9.6, $\mathrm{NaCI} 6,5 \%$ ) (Guiraud, 1998; Joffin and Leyral, 2001).

\section{Protocol of nisin production}

The production protocol used was modeled on those made by several authors (Barefoot et al, 1983; Lachance, 2000;
Sebti, 2002; Doumandji et al, 2010). Nisin production started with a pre-culture of the strain Lc.lactis ssp. lactis previously isolated. First, the pre-culture was obtained by inoculating sterile test tubes containing $9 \mathrm{ml}$ of M17 broth with $1 \mathrm{ml}$ of culture of more than 24 hours of the strain Lc.lactis ssp. Lactis, isolated from camel milk cheese, in the same broth. The tubes were incubated at $30^{\circ} \mathrm{C}$ with shaking at $140 \mathrm{rpm}$ for $18 \mathrm{~h}$ in an incubator shaker. To facilitate the diffusion of the bacteriocin of Lactococcus lactis, M17 medium was used. $100 \mathrm{ml}$ of this medium was divided into two Erlen Meyers $(100 \mathrm{ml})$, enriched with $1 \%$ glucose and sterilized for 20 minutes at $120^{\circ} \mathrm{C}$. Then the M17 medium was inoculated with $10 \%$ of the preculture Lc.lactis ssp. lactis, and the culture was incubated for 18 to $24 \mathrm{~h}$ at $30^{\circ} \mathrm{C}$ with shaking at $140 \mathrm{rpm}$. For recovery of the supernatant, the bacterial culture was distributed in hemolysis tubes $(5 \mathrm{ml})$ and centrifuged at $8000 \mathrm{~g}$ for 20 min using a refrigerated centrifuge; the supernatant was carefully recovered with removal bacterial cells collected from the bottom of the tubes. To eliminate the effect of organic acids, the $\mathrm{pH}$ of the supernatant was adjusted to 6 with $\mathrm{NaOH}(1 \mathrm{~N})$.

\section{Isolation and identification of the target strain Pseudomonas fluorescens}

Psychotrophic strain Pseudomonas fluorescens was isolated from a milk sample stored at $7^{\circ} \mathrm{C}$ for 10 days according to Milliere and Veillet-poncet (1979).

The identification of the isolated strain was achieved by macroscopic and microscopic examination (fresh state and after Gram staining), physiological tests such as growth in nutrient broth at different temperatures $\left(4^{\circ} \mathrm{C}, 43^{\circ} \mathrm{C}\right)$ and in media: King A and King B. identification was performed using an API $20 \mathrm{E}$ miniaturized gallery (Biomérieux) (Guiraud, 1998; Vezina and Lacroix,2000).

\section{Study of the inhibitory activity of nisin against Pseudomonas fluorescens}

The antimicrobial activity of the supernatant recovered from culture of Lactococcus lactis subsp. lactis was tested using various methods of gel diffusion technique recommended by Tag et al. (1976). It was based on the appearance of a zone of inhibition caused by the culture supernatant containing the bacteriocin, deposited in wells, or even soaked on spots or disks.

The inoculum of the test strain (Pseudomonas fluorescens) was prepared in sterile test tubes on inoculating $5 \mathrm{ml}$ of sterile saline with a colony of the test strain taking from nutrient agar medium. Three Petri dishes containing Mueller Hilton medium (MHA) were inoculated by the target organism (Psendomonas fluorescens). On each box dug wells using the tip of a sterile Pasteur pipette (4.5 $\mathrm{mm}$ diameter) were filled 
by $50 \mu \mathrm{l}$ of supernatant. The Petri dishes were prepared and pre-incubated for $2-4$ hours at $4^{\circ} \mathrm{C}$ to allow the radial diffusion of the inhibitor. Incubation is then carried out at $30^{\circ} \mathrm{C}$ for 18 to 24 hours under aerobic conditions. For spots method, $10 \mu$ l of the supernatant to be tested were deposited on the surface of the agar using a micropipette. The dishes were steamed for 18 to $24 \mathrm{~h}$ at $30^{\circ} \mathrm{C}$.

The desired result was manifested by the presence of clear zones of inhibition in cloudy water formed by the growth of the target strain (Izquierdo, 2009). Then, for discs method according to Tadesse (2004).

- Flooding the surface of the Petri dishes containing Mueller-Hilton medium by inoculum of the target strain

-drying the dishes for $30 \mathrm{~min}$ at $30^{\circ} \mathrm{C}$. After drying, deposited on the surface of the agar discs sterile filter paper previously impregnated by bacteriocinic supernatant, then once dry even boxes for $30 \mathrm{~min}$,

- Placing the boxes at $4^{\circ} \mathrm{C}$ for $4 \mathrm{~h}$ ensured the dissemination of the bacteriocin, and then incubating the dishes at $30^{\circ} \mathrm{C}$ for 24 hours.

Reading the bacteriocin's activity was done by measuring the diameter of inhibition around wells or inhibitory zones (Iz) in mm (Allouache et al., 2010). Inhibition was considered positive if the diameter (Iz) was larger than $2 \mathrm{~mm}$ according to Doumandji et al. (2010). Measuring the inhibition diameter (Iz) was performed according to the following formula.

Iz in $(\mathrm{mm})=$ diameter of the inhibition zone obtained $(\mathrm{mm})-$ diameter of wells $(4,5 \mathrm{~mm})$

The antibacterial activity in arbitrary units per $\mathrm{ml}(\mathrm{AU} / \mathrm{ml})$, according to Champagne (2007), was calculated from the highest dilution (D) where there was still the presence of an inhibition of more than 2 area $\mathrm{mm}$, according to the following equation:

$\mathrm{A}(\mathrm{UA} / \mathrm{ml})=(1000 / 10 \mu \mathrm{l})(\mathrm{l} / \mathrm{D})$

\section{RESULTS}

\section{Physico-chemical analyses}

Camel milk samples analyzed are apostrophized by a titratable acidity of about $17,8 \pm 0.5^{\circ} \mathrm{D}$. The values of their density and $\mathrm{pH}$ at $\left(\mathrm{T}=20^{\circ} \mathrm{C}\right)$ are respectively $1,028 \pm 0.001$ and $6,56 \pm 0.002$.

\section{Bacteriological quality of camel milk}

Discoloration of methylene blue of the analyzed camel milk sample occurred after a longer than 4 hours. This milk had a good bacteriological quality. It contained less than
$2.10^{6}$ cells $/ \mathrm{ml}$ by referring to the grid of Larpent, 1970 and Guiraud, 1998.

\section{Isolation and identification of bacterial strains Isolation and Identification of Lactococcus lactis ssp. lactis}

The isolated strain was devoid of catalase and oxidase. It was immobile. It ferments glucose giving only lactic acid (homofermentative). It cannot hydrolysis neither arginine nor citrate. It grew at $\mathrm{pH} 9,6$ and $45^{\circ} \mathrm{C}$. The results of physiological and biochemical tests were used to identify the isolated strain as a strain belonging to the species Lactococcus lactis ssp. lactis (Guiraud, 1998).

\section{Isolation and Identification of Pseudomonas fluorescens}

The isolated strain was catalase positive, oxidase positive, and did not react with methyl red (RM negative reaction). It degraded glucose, arabinose and melibiose, aerobically on the gallery API $20 \mathrm{E}$. Also, it hydrolyzed arginine and gelatin in the same gallery. Growth on nutrient broth $(\mathrm{BN})$ was recorded at $4{ }^{\circ} \mathrm{C}$ and not at $43^{\circ} \mathrm{C}$. Pyoverdine production (pigment) was displayed on King B (fluorescent green) environment. The morphological characters and different biochemical and physiological tests could identify isolated strain as belonging to the species Pseudomonas fluorescens strain (Guiraud, 1998).

\section{Study of the antibacterial activity of the extract of nisin on Pseudomonas fluorescens}

The measurement of average diameters of inhibition zones (Iz) for Wells and Discs method were respectively 8, 75 $\pm 0,01$ (for 4 Wells positives) and 20, 05 \pm 0,015 (for 10 Discs positives).

The method of critical dilution of supernatant was used to calculate the antibacterial activity in arbitrary units (AU) according to equation of Champagne (2007).

$\mathrm{A}(\mathrm{UA} / \mathrm{ml})=(1000 / 10 \mu \mathrm{l}) \times(\mathrm{l} / \mathrm{D})$.

Since maximum dilution to give a further inhibition of a diameter greater than $2 \mathrm{~mm}$ by the method of spot area is the $1 / 32$ dilution.

$\mathrm{A}(\mathrm{UA} / \mathrm{ml})=1000 / 10 \times 1 / 1 / 32$

$\mathrm{A}=3200 \mathrm{UA} / \mathrm{ml}$

\section{DISCUSSION}

The three methods of gel diffusion gave positive results with the appearance of inhibition zones (Iz) distinctive (apparent halos) around spots, wells and disks. The results were illustrated by Figs. 1, 2 and 3. The (Iz) had varying 


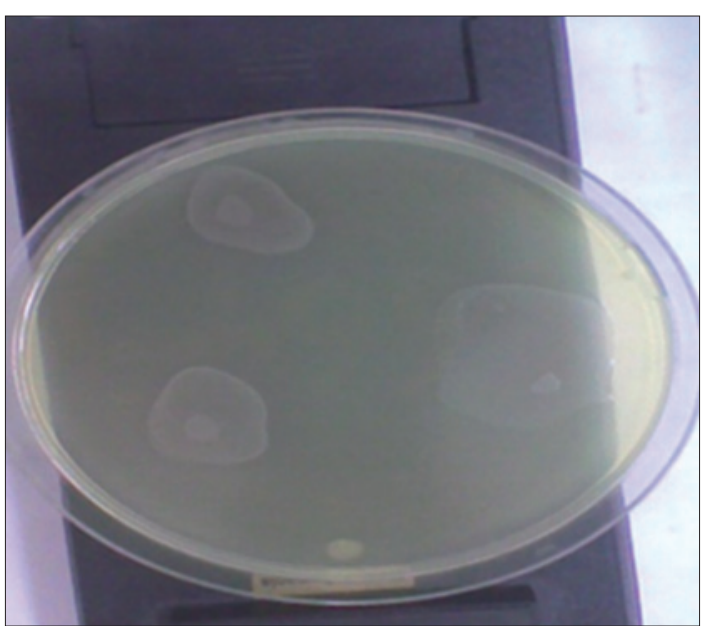

Fig 1. Antibacterial activity of supernatant against Ps fluorescens by the method of spots.

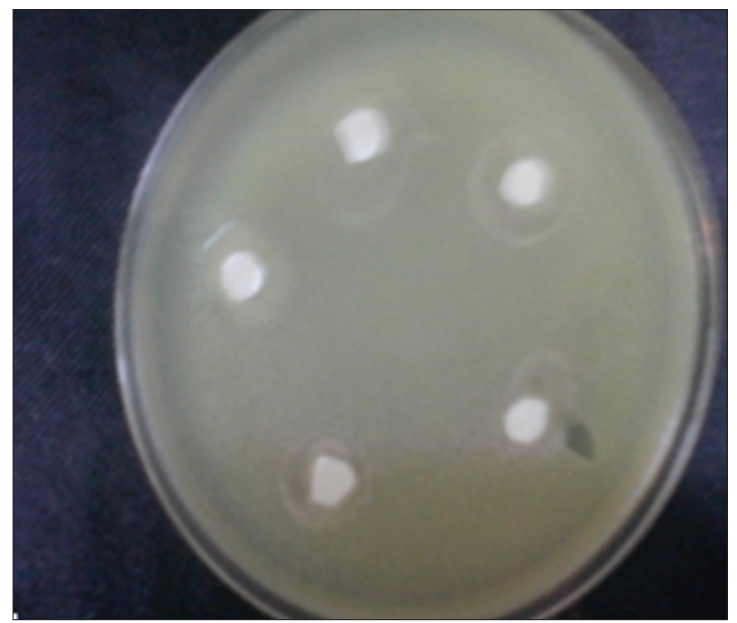

Fig 2. Antibacterial activity of supernatant against Ps fluorescens by the disc method.

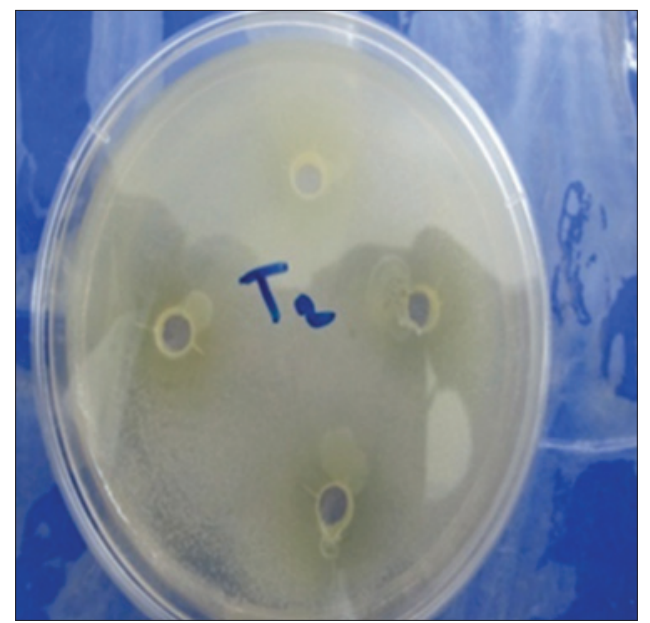

Fig 3. Antibacterial activity of supernatant against Ps fluorescens by the method of well.

diameters. This study showed also that the method of spots was less suitable. This could be due to the poverty of supernatant's distribution or to the insufficient diffusion of bacteriocin. The estimated using the critical dilution of antibacterial activity used by Mayr (1972) was equal to $3200 \mathrm{AU} / \mathrm{ml}$. This may be more or less accepted, Meghrous et al. (1999) reported that the estimation of the activity of a bacteriocin by the method of diffusion in agar was a relative measure, because the sensitivity of the target bacteria, the growth medium used, the concentration of the test agar medium, and the concentration of bacteriocin were all factors that may affect results.

Generally, bacteriocins of lactic acid bacteria were not active against Gram-negative bacteria. This was due to the difference in the composition of the cell envelope of Gram positive and Gram negative bacteria. However, some studies suggested that changes in permeability properties of the outer membrane after some treatments used (the addition of EDTA, lysozyme.) in combination with bacteriocins or stress conditions would make sensitive Gram-negative bacteria to bacteriocins (Abee, 1995; Cintas et al., 2001; Deegan et al., 2006).At our knowledge, no studies on the effect of nisin used only on Pseudomonas have been reported in the literature. However, the spectrum of activity of some bacteriocins (such as nisin) according to Klaenhammer (1993) may not be restricted to taxonomically related species or even occupying the same ecological place of the producing bacteria. From a practical point of view, the field of activity of a bacteriocin may be larger or smaller depending on the environmental conditions and the concentration of active substance.

\section{CONCLUSION}

This study was contributing to improve the keeping quality of camel milk usually consumed fresh and also to master the technique of its transformation into a cheese complies with the requirements of the consumer, by reducing its psychrotrophic flora responsible for bitterness defects and bad tastes. It is possible to use nisin produced by a strain of camel origin for the preservation of chilled camel milk. Finally, the isolation of lactic acid bacteria especially from cheese or camel milk and highlighting their antagonistic power production of bacteriocins against Gram-negative flora, constituted an interesting topic to extend because little informations are available in the literature on these microorganisms.

\section{Authors' contributions}

W. Souid is the principal author of this work. She has made major contributions to this article in sampling, physicochemical analysis of milk samples, identification isolation etc.). S. Boudjenah-Haroun was Involved in the production of the cheese using the enzyme extracts coagulants of dromedary also in conception and design 
of study. OK. Siboukeur Was Involved in microbiological analysis of milk samples and bacterial isolation and identification. A. Mati Was Involved in supervisor of the research project which is affiliated to his laboratory.

\section{REFERENCES}

Abee, T. 1995. Pore-forming bacteriocins of gram-positive bacteria and self-protection mechanism producer organism. FEMS Microbiol. Lett. 129: 1-10.

Abu-taraboush, H., M. Al-dagal, A. Al-royli. 1998. Growth, viability, and proteolytic activity of Bifidobacteria in whole camel milk. J. Dairy Sci. 81: 354-361.

Akhmetsadykova, S., G. Konuspayeva, G. Loiseau, A. Baubekova, S. Kanayat, N and B. Faye. 2013. Protection against lead contamination by strains of lactic acid bacteria from fermented camel milk. Emirates J. Food Agric. 25: 274-282.

Allouache, F., A. Hellal, A. Laraba. 2010. Study of the antimicrobial activity of thermophilic lactobacilli strains used in the dairy industry. J. Natr. Technol. 03: 13-20.

Ayman, A., H. Alaa, E. Eisa. 2009. Identification of lactic acid bacteria isolated from traditional Sudanese fermented camels milk (Gariss). Afr. J. Microbiol. Res. 3: 451-457.

Badaoui, D. 2000. Contribution to the knowledge of camel milk: Test characterization of proteins by electrophoresis on poly-Acryl amide gel (PAGE). Thesis of Engineer in agronomy. Institute of Saharian Agronomy. University of Ouargla.

Barefoot, S. and T. Klaenhammer. 1983. Detection and activity of lacticin B, a bacteriocin produced by Lactobacillus acidophilus. Appl. Environ. Microbiol. 45: 1808-1815.

Boudjenah-haroun, S., C. L. Laleye, F. Moulti-mati, S. Si ahmed, N. Mahboub, O. Siboukeur and A. Mati. 2011. Comparative study of milk clotting activity of crude gastric enzymes extracted from camels abomasum at different ages and commercial enzymes (pepsin and rennet) on bovine and camel milk. Emirates J. Food Agric. 23(4): 301-310.

Cintas, L., M. Casaus, C. Herranz, I. Born and P. Hernandez. 2001. Review: Bacteriocins of lactic acid bacteria. Food Sci. Technol. Int. 7: 281-305.

Deegan, L., P. Cotter, C. Hill and P. Ross. 2006. Bacteriocins: Biological tools for bio-preservation and shelf-life extension. Int. Dairy J. 16: 1058-1071.

Dortu, C. and P. Thonart. 2009. Les bactériocines des bactéries lactiques: Caractéristiques et intérêts pour la bioconservation des produits alimentaires. Biotechnol. Agron. Soc. Environ. 13(1): 143-154.

Doumandji, A, A. Hellal and N. Saidi. 2010. Purification of a bacteriocin from Lactobacillus acidophilus. Rev. Microbiol. Ind San et Environ. 4(2): 25-47.

Edima, C. 2007. Carnobacterium maltaromaticum: Physiological and potential characteristics in cheese industry. PhD at INPL University of Nancy, France.

Faye, B., G. Saint-Martin, P. Bonnet, M. Bengoumi and M. L. Dia. 1997. Guide de L'élevage du Dromadaire. Ed. Libourne: Sanofi; Pp. 38-39.

Gorban, A. and S. Izzeldin .1999. Study on cholesterol ester fatty acids in camel and cow milk lipid. Int. J. Food Sci. Technol. 34: 229-234.

Goursaud, J. 1985. Composition et propriétés physico - chimiques. Les laits de la mamelle à la laitière. In: Luquet FM, editor. Dans
Laits et Produits Laitiers Vache, Brebis, Chèvre. Tome. 1. Tec. et Doc. Lavoisier, Paris.

Guiraud, J. P. 1998. Food Microbiology. Dunod Edition, France.

Haider, K., H. A. Izhar and A. Muhammad. 2004. Evaluation of cheese prepared by processing camel milk. Pak. J. Zool. 36: 323-326.

Jaouen, J. 1993. National Good Practice Guide in Cheese Production Farm. Vol. 3. Institute of Animal Husbandry, Paris, Pp. 123-144.

Joffin, G. and J. N. Leyral. 2001. Microbiology - Technical Dictionary. $3^{\text {rd }}$ ed. Collection Biology Technique. CRDP d'Aquitaine, Bordeaux.

Kalchayanand, N., T. M. Arthur, J. M. Bosilevac, J. W. Schmidt, R. Wang, S. D. Shackelford. and T. L. Wheeler. 2012. Evaluation of commonly used antimicrobial interventions for fresh beef inoculated with shiga toxin-producing escherichia coli serotypes O26, O45, O103, O111, O121, O145, and O157:H73. J. Food Prot. 75: 1207-1212.

Klaenhammer, T. 1993. Genetics of bacteriocins produced by lactic acid bacteria. FEMS Microbiol. Rev. 12: 39-86.

Konuspayeva, G., B. Faye, A. Baubekova and G. Loiseau. 2012. Camel gruyere cheese making. Proc. $3^{\text {rd }}$ ISOCARD conference, $29^{\text {th }}$ January $-1^{\text {st }}$ February, 2012, Mascate (Sultanate of Oman), 218-219.

Konuspayeva, G., B. Camier, F. Gaucheron and B. Faye. 2014. Some parameters to process camel milk into cheese. Emirates J. Food Agric. 26: 354-358.

Lachance, M. 1983. Purification and characterization of a bacteriocin produced by Lactococcus lactis ssp. lactis MJC15. Department of Food Science and Nutrition. University Laval, Qc, Canada.

Larpent, P. 1997. Food Microbiology: Laboratory Techniques. Ed Tech and Doc Lavoisier, Paris.

Law, J. and A. Haandrikman. 1997. Proteolytic enzymes of lactic acid bacteria. Int. Dairy J. 7: 1-11.

Mathieu, J. 1998. Introduction to the physical chemistry of milk. Tec \& Doc Lavoisier, Paris.

Mayr, H. 1972. Methods for studying bacteriocins. In: Method in Microbiology. Norris, R. J. and D. W. Ribbons. (Eds.), Academic Press, New York, Pp. 315-322.

Meghrous, J., F. Goulhen and C. Lacroix. 1999. Production of a nisin $\mathrm{Z} /$ pediocin mixture by $\mathrm{pH}$-controlled mixed-strain batch cultures in supplemented whey permeates. J. Appl. Microbiol. 86: 399-406.

Milliere, B-J. and L. Veillet-poncet. 1979. Determination of psychrotrophic caseolytic bacterial flora raw milk refrigerated. Milk. 56:581-582.

Nielsen, S. 2002. Plasmin system and microbial proteases in milk: Characteristics, roles, and relationship. J. Agric. Food Chem. 50: 6628-6634.

O'Sullivan, L., R. P. Ross and C. Hill. 2002. Potential of bacteriocinproducing lactic acid bacteria for improvements in food safety and quality. Biochemistry. 84: 593-604.

Petransexie, M., L. Serres and P. Amarigios. 1973. Physical and chemical analyzes. In: Control the Quality of Dairy Products, Directorate of Veterinary Services. Ministry of Agriculture, France.

Saidi, M., O. Siboukeur, A. Ouled belkheir and Guerradi. 1999. Physicochemical characteristics, composition and bacteriological quality of camel milk Sahrawi population (Wilayates Ouargla and Ghardaia). Technological skills. First day on the Camel Research Ouargla, Pp. 129-133.

Saley, M. 1993. Production of Camel Dairy. CIRAD, Ed MaisonsAlfort, Paris. 
Sboui, A., T. Khorchani, M. Djegham and O. Belhadj. 2009. Comparison of the physico-chemical composition of camel and bovine milk of southern Tunisia, variation of $\mathrm{pH}$ and acidity at different temperatures. Afr. Sci. 05: 293-304.

Sebti, I. 2002. Bio-active packaging incorporating nisin dissemination of this bacteriocin in agarose gel. PhD Thesis. France.

Tagg, J., A. Dajani and L. Wannamaker. 1976. Bacteriocins of grampositive bacteria. Rev. Microbiol. 40: 722-756.

Thompson, J., M. Collins and W. Mercer. 1996. Characterization of a proteinaceous antimicrobial produced by Lactobacillus helveticus 450 CNRZ. J. Appl. Bacteriol. 80: 338-348.

Valles, E. and J. P. Furet. 1977. Etude des caillettes des bovins à l'état ruminant pour l'obtention d'extraits coagulants à base de pepsine bovine; Méthodes d'extraction. Lait. 61: 601-617.

Vezina, L. and M. Lacroix. 2000. Conventional biochemical tests for identification of Pectobacterium (Erwinia pectinolytic) and fluorescent pseudomonas. Diagnostic laboratory phytoprotection-MAPAQ. Pp. 2-6. 